\title{
Mental healthcare in Poland
}

\section{Jacek Bomba}

Chair of Psychiatry, Jagiellonian University Collegium Medicum, Kopernika 21 A, 31501 Kraków, Poland, email jacek.bomba@uj.edu.pl

M odern mental healthcare in Poland has its foundations in the 19th century, when the country was subject to three different organisational and legal systems - of the Austrian, Prussian and Russian Empires. These differences prevailed even after the First World War. Professionals lobbying for a mental health act had no success. The Second World War left mental healthcare with significant losses among its professional groups. More than half of all Polish psychiatrists lost their lives; some of them were exterminated as Jews, some as prisoners of the Soviets. The Nazi occupation in Poland had dramatic consequences for people with a mental disturbance, as Action T4 turned into genocide on the Polish territory. The majority of psychiatric in-patients were killed. After the Second World War, the mental health system had to be rebuilt, almost from scratch. Major political changes in the country across the second part of the 20th century and revolutionary changes in mental healthcare around the world influenced psychiatric services. The purpose of this paper is to describe mental healthcare in Poland today.

\section{Mental health policy and legislation}

The national mental health policy emphasises promotion, prevention, treatment and rehabilitation; it was initially formulated in 1995 as the National Mental Health Programme. This was followed by the development of regional mental health programmes, specifying particular tasks in each of Poland's voivodships (provinces). However, their realisation is far from satisfactory.

The Mental Health Act enacted in 1994 regulates:

o the promotion of mental health

the prevention of mental disorders and discrimination

the provision of accessible mental healthcare services in the community

the protection of the civil rights of people with mental disorders.

The Act also regulates involuntary treatment. Other acts concern the prevention of alcohol and drug misuse, rehabilitation and employment of people with disabilities; the Penal Code and the Civil and Care Codes also have a bearing on people with mental illness.

The treatment of severe mental disorders is largely free of charge (in-patient treatment, community care, consultations, psychotherapy, rehabilitation and a significant part of medication). Policy regarding the provision of therapeutic drugs is based on a parliamentary act that divides drugs into two groups: 'basic' compounds and 'additional' compounds. The latter include new drugs. The Minister of Health decides which drugs will be supplied free of charge, or at low or reduced prices for persons with specific disorders.

\section{Mental health service delivery}

Mental healthcare is included within the primary care system, although most of it is undertaken within the mental health out-patient clinic system, which is well developed and easily accessible. Primary care physicians are trained in psychiatry, including family psychiatry. However, systemic changes in healthcare financing have disrupted services. Nonetheless, deinstitutionalisation has been continued, and the numbers of day centres, psychiatric units in general hospitals and mobile community teams are increasing. In spite of this, the majority of psychiatric beds are still in psychiatric hospitals (5.2 per 10000 population) rather than general hospitals (1.2 per 10000). The overall number of mental health professionals is not satisfactory (Fig. 1); in addition, they are unevenly distributed across the country.

Mental healthcare, as one aspect of general healthcare, is financed by the National Health Fund (NHF), an obligatory, tax-based health insurance system. The NHF, in cooperation with the regional governments, is responsible for satisfactory provision of services. In-patient treatment is financed by the $\mathrm{NHF}$, as is the majority of out-patient care $(82 \%$ of such care for adults in 2004-05, 94\% for children in 2005; Institute of Psychiatry and Neurology, 2006).

In addition, consultation and psychotherapy facilities within the social care system have an important role in the provision of mental healthcare, as do programmes appointed by local authorities and within the educational system (for children, adolescents and their families).

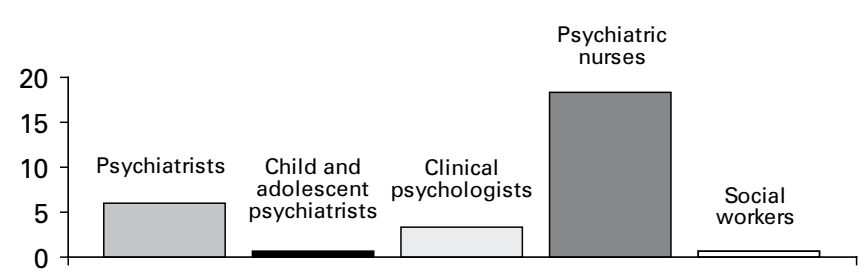

Number of professionals per 100000 population

Fig. 1 Numbers of mental health professionals (Institute of Psychiatry and Neurology, 2006). 


\section{Psychiatric training}

\section{Undergraduate}

Undergraduate training in psychiatry is based upon a national curriculum. However, medical schools have developed their own programmes, often more extended than the national curriculum. Many specific subjects are taught within elective courses. For example, the programme at the Jagiellonian University Collegium Medicum, Krakow, in addition to a basic course in psychiatry covering child and adolescent psychiatry, general psychiatry and old age psychiatry, also includes medical psychology and basic psychotherapy (which are obligatory), as well as psychoanalysis and sexology (elective).

\section{Postgraduate}

Since 1999, postgraduate training in psychiatry has been a 5-year residency programme based on standards developed by the Section of Psychiatry of the European Union of Medical Specialists. The rotation scheme is dominated by general psychiatry in in-patient settings; however, out-patient services, community psychiatry and psychotherapy centres are also obligatory. Child and adolescent psychiatry, intellectual disabilities, old age psychiatry and forensic psychiatry, although obligatory, are not given adequate amounts of time (Table 1). The theoretical part of training is organised as a series of courses that training centres are obliged to deliver.

\section{Psychiatric sub-specialties}

In 1999, postgraduate training in child and adolescent psychiatry was organised as an additional 2 years of residencybased programme for psychiatrists. The number of trainees then significantly decreased, endangering the future of mental healthcare for children and adolescents. To prevent this, a 5 -year training programme for physicians was introduced.

\section{Allied professions}

Psychiatric nurses have a two-stage undergraduate university training in general nursing (3 years to become a licensed nurse and a further 3 years to obtain an MSc). Postgraduate training in psychiatric nursing follows a national curriculum and comprises 300 hours of theory and 560 hours on rotations.

Psychologists have a 5-year undergraduate training that is based on a national curriculum, although the final programme is designed by the universities. Postgraduate training in clinical psychology was suspended in the late 1990s because of major legal changes to the profession; it was reintroduced in 2004 . It comprises a 5-year rotation-based training scheme that follows a national curriculum.

The regulation of postgraduate training in psychotherapy is presently being discussed. Until now, the Polish Psychiatric Association, Polish Psychological Association and several other psychotherapeutic societies have provided training and certification procedures (the two named organisations being the main ones; only their certificates are recognised by the NHF).

\section{Research}

The majority of research in the mental health field is conducted at the governmental Institute of Psychiatry and Neurology and research centres in medical schools across the country. Research projects can be supported by grants
Table 1 Postgraduate training in psychiatry (numbers of hours)

(numbers of hours)

1st 2nd 3rd 4th 5th

year year year year year

\begin{tabular}{|c|c|c|c|c|c|}
\hline \multicolumn{6}{|l|}{ Mandatory practical training } \\
\hline In-patient unit, short stay & 8 & & & & \\
\hline In-patient unit & 3 & 4 & 3 & 4 & \\
\hline Child and adolescent psychiatry service & & 4 & & & \\
\hline Neurology & & 3 & & & \\
\hline Neurotic disorders service & & & 6 & & \\
\hline Community psychiatry service & & & 2 & & \\
\hline Out-patient service & & & & 5 & \\
\hline Consultation-liaison psychiatry & & & & 2 & \\
\hline Substance dependency service & & & & & 3 \\
\hline Facultative & & & & & 8 \\
\hline \multicolumn{6}{|l|}{ Theoretical courses } \\
\hline Foundations of psychiatry & 80 & & & & \\
\hline Health promotion & 25 & & & & \\
\hline Psychotherapeutic relations & & 40 & & & \\
\hline $\begin{array}{l}\text { Foundations of child and adolescent } \\
\text { psychiatry }\end{array}$ & & 40 & & & \\
\hline Introduction to family therapy & & & 40 & & \\
\hline Clinical practice of psychotherapy & & & & 40 & \\
\hline Forensic psychiatry & & & & 35 & 40 \\
\hline Balint Seminar (recommended) & 20 & 20 & 20 & 20 & 20 \\
\hline
\end{tabular}

from the Ministry of Science and Higher Education, and by international sources. Several research groups participate in collaborative projects run by the World Health Organization and the European Union. These are mainly studies of the genetics of mental disorders, the epidemiology of mental disorders, economics, health promotion and combating stigma. Affective disorders, schizophrenia, cognitive disorders, child and adolescent mental health problems, and old age mental disorders are approached from different perspectives.

A long-term prospective study of people diagnosed with schizophrenia, being carried out in Krakow, deserves special mention (Cechnicki, 1998).

The effectiveness of psychotherapy has been extensively studied. The problem has been approached by tracking changes in symptoms and personality traits in response to psychotherapy in the treatment of patients with neuroses (Aleksandrowicz, 1991); additionally, symptoms, defence mechanisms and quality of life have been looked at in the integrated treatment of patients suffering schizophrenic and affective disorders (Bomba \& Cichocki, 2005; Zieba et al, 1997).

Methods of rehabilitation and community care and their effectiveness are yet another group of problems researchers are concerned with (Meder \& Cechnicki, 2002).

Eating disorders, which have significantly increased in incidence in recent decades, have also been given special attention (Józefik \& Pilecki, 2004).

For the last 50 years, starting with the group of Auschwitz concentration camp survivors, the consequences of trauma have been studied (Kepinski, 1970). Also studied have been Holocaust survivors (Orwid et al, 2002) and prisoners of the former political Soviet and communist regime (Heitzman \& Rutkowski, 2002); second- and third-generation survivors have been studied consecutively. Methods of treatment for the various forms of post-traumatic stress disorder will form the next important research topic.

Results of studies are published in both international and Polish journals. The major Polish psychiatric journals are Psychiatria Polska (in Polish, with English, French, German 
and Russian abstracts) and Archives of Psychiatry and Psychotherapy (in English).

\section{Human rights issues}

From the late 1940s to the 1980s, as the Polish Psychiatric Association watching group noted (Bomba et al, 1993), there was no abuse of psychiatry for political reasons. Since 1994 the Mental Health Act has provided for the prevention of abuse of the right to personal freedom in psychiatric practice. Professionals are obliged to offer treatment, if needed, after obtaining informed consent. The major human rights issue remains deprivation of privacy in psychiatric wards due to chronic unsatisfactory funding (Buda et al, 1998).

\section{References}

Aleksandrowicz, J. (1991) Psychotherapiefgorschung in Polen. [Psychotherapy research in Poland.] In Psychoterapie in der Medizin [Psychotherapy in medicine] (ed. E. Brahler). Westd Verl.

Bomba, J. \& Cichocki, Ł. (2005) Czy neuroscience wyjasnia efekty psychoterapii schizofrenii? [Does neuroscience explain the effects of psychotherapy in schizophrenia?] Psychoterapia, 2, 5-11.

Bomba, J., Szymusik, A. \& Piotrowski, A. (1993) Psychiatry in Eastern Europe. American Journal of Psychiatry, 150, 988-989.
Buda, B., Gondios, A. \& Demetrovics, Z. (eds) (1998) Costs of Rights in Psychiatry. CLPI.

Cechnicki, A. (1998) Analiza wpływu wybranych czynników na wyniki leczenia w obszarze społecznym. Krakowskie prospektywne badania przebiegu schizofrenii. [Selected factors impact on social area results of schizophrenia treatment. The Krakow prospective follow-up study.] Badania Nad Schizofrenia, 1, 37-48.

Heitzman, J. \& Rutkowski, K. (2002) Mental disturbances in former political prisoners persecuted in Poland in the years 1944-1956. Dialog. Zeszyty Polsko-Niemieckiego Towarzystwa Zdrowia Psychicznego, Hefte dre Deutsch-Polnishen Gesellschaft fur Seeliche Gesundheit, 11, 206-211.

Institute of Psychiatry and Neurology (2006) Zakłady psychiatrycznej oraz neurologicznej opieki zdrowotnej. Rocznik statystyczny 2005. [Psychiatric and neurological health care services. Statistical yearly 2005.] Institute of Psychiatry and Neurology.

Józefik, B. \& Pilecki, M. (2004) Therapeutic implications of the individual, familial and cultural context of eating disorders in Poland. World Psychiatry, 3 (suppl. 1), 293.

Kepinski, A. (1970) The so-called 'KZ-syndrom' - an attempt at a synthesis. Przeglad Lekarski, 26, 18-23. Reprinted in Przeglad Lekarski, Krakow, 141-156 (ed. J. Z. Ryn, 2002).

Meder, J. \& Cechnicki, A. (2002) Rehabilitation of the mentally ill in Poland. In Images in Psychiatry. Poland (eds A. Bilikiewicz \& J. Rybakowski), pp. 142-157. WPA, PTP, Via Medica.

Orwid, M., Domagalska-Kurdziel, E., Kaminska, M., et al (2002) The Holocaust in Polish publications. In Images in Psychiatry. Poland (eds A. Bilikiewicz \& J. Rybakowski), pp. 83-114. WPA, PTP, Via Medica.

Zieba, A., Dudek, D. \& Jawor, M. (1997) Cognitive style in depressed patients over three-year follow-up. European Journal of Psychiatry, 11, 244-250.

\section{Mental health in New Zealand}

\section{A. P. McGeorge QSO FRANZCP}

Oceania Vice-President, World Federation for Mental Health, email peter.mcgeorge@gmail.com

N ew Zealand's healthcare system has undergone significant changes in recent times, among them being the establishment in 1993 of a purchaser/provider split and the specific attention given to the development of mental health services. Funding for mental health services (Fig. 1) increased from NZ\$270 million in 1993/94 to NZ\$866.6 million per annum in 2004/05, a real increase (adjusted for inflation) of $154 \%$ (Mental Health Commission, 2006). The bi-partisan political commitment sustaining this funding has had a major impact on the development of recoverybased and culturally specific models of care unrivalled by few countries in the world. However, recent reports (Mental Health Commission, 2006) indicate that, particularly with regard to access, much still remains to be done to address the mental health needs of New Zealanders.

New Zealand is a Pacific country of 4.15 million people. At the last census (2001), with three responses allowed per person, $80 \%$ identified themselves as being European, 15\% as being indigenous Maori, 6.5\% Pacific Island and 6.6\% Asian, with other ethnicities accounting for less than $1 \%$ of the population. These categories are very broad and only partially describe the situation that exists in New Zealand. For example, while $91 \%$ identified with one ethnicity, $44 \%$ of
Maori identified with multiple ethnicities (Ministry of Social Development, 2006).

The median age of the population is 36 years. The overall male/female gender ratio is 0.99 . The unemployment rate currently stands at around $4 \%$.

\section{Healthcare structure}

While there is a substantial private sector in medicine and particularly in surgery, the public and not-for-profit sectors dominate over the private sector in the delivery of mental health services. For example, less than $10 \%$ of psychiatrists in New Zealand work in the private sector.

The Ministry of Health oversees the development and delivery of health services. It implements government policy and is responsible for the regulation and statutory oversight of the Mental Health Act 1992.

Health services are funded by the Ministry via 21 district health boards, which are responsible for the health of defined populations and catchment areas. Each district health board, guided by the objectives of the Ministry of Health's $2000 \mathrm{New}$ Zealand Health Strategy and 2001 New Zealand Disability 